\title{
The Role of Dopamine Receptors in Regulating the Size of Axonal Arbors
}

\author{
C. L. Parish, ${ }^{1}$ D. I. Finkelstein, ${ }^{1}$ J. Drago, ${ }^{1,2}$ E. Borrelli, ${ }^{3}$ and M. K. Horne ${ }^{1,2}$ \\ ${ }^{1}$ Neurosciences Group, Department of Medicine and ${ }^{2}$ Department of Neurology, Monash Medical Center, Clayton 3168 , \\ Australia, and 3/nstitut de Génétique et de Biologie Moléculaire et Cellulaire, 67404 Illkirch Cedex, France
}

Factors that regulate terminal arbor size of substantia nigra pars compacta (SNpc) neurons during development and after injury are not well understood. This study examined the role of dopamine receptors in regulating arbor size. Terminal arbors were examined in mice with targeted deletion of the D1 or D2 dopamine receptor [D1(-/-) and D2(-/-) mice, respectively]. Terminal trees were also examined after treatment with receptor blockers and after partial SNpc lesions. Immunohistochemistry was performed, and the number of SNpc neurons and dopaminergic terminals in the striatum was estimated. The number of dopaminergic SNpc neurons were reduced in D1(-/-) and D2(-/-) mice. Density of dopaminergic terminals was unchanged in D1(-/-) mice and increased in D2 (-/-) mice. Steady-state striatal DA and DOPAC levels revealed that dopamine activity was enhanced in D2(-/-) mice but reduced in D1 (-/-) mice.
Two months after partial SNpc lesions, striatal terminal density was normal in both wild-type and D1(-/-) mice but reduced in D2(-/-) mice. Administration of DA receptor antagonists resulted in larger terminal arbors in D1(-/-) and wildtype mice, whereas D2(-/-) mice showed no change in terminal density.

Functional blockade of the D2R during development or in the adult brain results in increased axonal sprouting. Partial SNpc lesions resulted in compensatory sprouting, only in mice with functional D2R. These results suggest that individual dopaminergic axons in D2(-/-) mice have reached maximal arbor size. We conclude that the $\mathrm{D} 2$ receptor may play a role in modulating the extent of the terminal arbor of SNpc neurons.

Key words: regeneration; dopamine receptors; sprouting; axonal arbor; dopamine antagonists; D1 receptor knock-out; D2 receptor knock-out; 6-OHDA lesions
There is now substantial evidence that neurons in the adult CNS can form new synapses, neurites, and branches (Raisman and Field, 1973; Fagan and Gage, 1994; Frotscher et al., 1997). After injury in the striatum or substantia nigra pars compacta (SNpc), a number of compensatory changes occur that suggest regenerative processes are present. These changes include the formation of new synaptic terminals, growth-cone structures (indicating axonal sprouting), neurite formation, increased number of tyrosine hydroxylase-immunoreactive (TH-IR) hypertrophic fibers penetrating the striatum, the upregulated expression of factors that support neurite outgrowth and cell survival, and increased dopamine levels (Zigmond et al., 1984; Onn et al., 1986; Hornykiewicz, 1993; Thomas et al., 1994; Blanchard et al., 1995, 1996; Cheng et al., 1998; Ho and Blum, 1998; Batchelor et al., 1999; Liberatore et al., 1999; Finkelstein et al., 2000).

Recently, we reconstructed single axons derived from SNpc neurons that survived small injections of the neurotoxin 6-hydroxydopamine (6-OHDA) (Finkelstein et al., 2000). The surviving neurons appeared to compensate for the partial denervation of the striatum by the acquisition of collateral branches and increased terminal numbers. When observed with electron mi-

Received Dec. 27, 2000; revised April 17, 2001; accepted April 26, 2001.

This work was supported by grants from the Bethlehem Griffith Foundation and the Australian National Health and Medical Research Council. J.D. is a Logan Fellow at Monash University. We thank J. Marriott (Pharmacy College, Monash University) for establishing HPLC in the laboratory and J. S. Massalas (Department of Medicine, Monash University) for technical assistance.

C.L.P. and D.I.F. contributed equally to this work.

Correspondence should be addressed to Prof. Malcolm Horne, Department of Neurology, Monash Medical Centre, Clayton Road, Clayton, 3168, Australia. Email: malcolm.horne@med.monash.edu.au.

Copyright (c) 2001 Society for Neuroscience 0270-6474/01/215147-11\$15.00/0 croscopy, the surviving terminals were $\sim 30 \%$ greater in size with a morphology that suggested enhanced efficiency (Finkelstein et al., 2000). Although the remaining axons formed very large terminal arbors, up to 10 times normal size in some neurons, it appeared that the sprouting was regulated, because sprouting was proportional to the size of the lesion. For example, the density of dopamine (DA) terminals in the striatum remained at near normal levels until neuronal loss in the SNpc reached $\sim 80 \%$ (Finkelstein et al., 2000). This suggested to us that the extent of sprouting might be regulated to maintain normal steady-state DA levels in the striatum. If this was so, it seems likely that DA receptors, either presynaptic on nigrostriatal terminals or postsynaptic on striatal neurons, might participate in mediating the extent of the sprouting response. The predominant receptor types expressed in the dorsal tier of the striatum (the target region for the SNpc) are the D1 dopamine receptor (D1R) and D2 dopamine receptor (D2R) (Bjorklund and Lindvall, 1984; Gerfen et al., 1987; Weiner et al., 1991; Missale et al., 1998), whereas only D2 receptor transcripts are identified in nigrostriatal neurons (Drago et al., 1998). The availability of knock-out mice, with target deletion of D1R (D1 (-/-) (Drago et al., 1994) and D2R (D2 (-/-) (Baik et al., 1995), provides an opportunity for investigating the role of these two receptors in modulating the extent of sprouting in development and after partial loss of neurons in the SNpc of the adult brain. The extent of sprouting in surviving neurons after a partial lesion of the SNpc in these animals was compared with that observed in wild-type (Wt) mice. In addition the DA receptor antagonists, haloperidol and $N$-ethoxycarbonyl-2-ethoxy-1,2dihydroquinoline (EEDQ) were administered to normal and knock-out animals to further assess the role of D1R and D2R in 
regulating terminal arbor size of dopaminergic projection neurons. Furthermore, knowledge of the contribution of D1R and $\mathrm{D} 2 \mathrm{R}$ in the modulation of compensatory responses may aid in the understanding and treatment of neurodegenerative disorders.

\section{MATERIALS AND METHODS}

D1 dopamine receptor-deficient mice were generated and genotyped as previously described (Drago et al., 1994). D1 $(+/+)$, heterozygous D1(+/-), and homozygous mutant D1 $(-/-)$ littermates were derived by interbreeding heterozygous mice. The heterozygous mice, originally in a hybrid C57/BL6 and 129/Sv genetic background had been backcrossed for four generations into a C57/BL6 background. D2 heterozygous mice were obtained from the original colony at Institut de Génétique et de Biologie Moléculaire et Cellulaire (Strasbourg, France). D2(+/+), D2 $(+/-)$, and D2 $(-/-)$ littermates were derived by interbreeding D2 heterozygous mice. Again, D2 heterozygous breeders had been backcrossed for four generations on a C57/BL6 background. All mice were kept in a temperature-controlled room $\left(22^{\circ} \mathrm{C}\right)$ under a $12 \mathrm{hr}$ light/dark cycle. All mice had ad libitum access to food and water and from the time of weaning, D1 $(-/-)$ mice were also provided with vitamized rat chow supplemented with peanut butter. Southern analysis was used to identify the genotypes of all mice (Drago et al., 1994; Baik et al., 1995).

All methods conformed to the Australian National Health and Medical Research Council published code of practice for the use of animal research and were approved by the Monash University Animal Ethics Committee.

\section{Immunohistochemistry for tyrosine hydroxylase and dopamine transporter}

Animals were killed by an overdose of sodium pentobarbitone (Lethobarb; $0.35 \mathrm{mg} / \mathrm{gm})$ and perfused with $30 \mathrm{ml}$ of warmed $\left(37^{\circ} \mathrm{C}\right) 0.1 \mathrm{M}$ PBS, $\mathrm{pH} 7.4$, with heparin $(1 \mathrm{U} / \mathrm{ml})$, followed by $30 \mathrm{ml}$ of chilled $4 \%$ paraformaldehyde (Sigma, St. Louis, MO) and $0.2 \%$ picric acid in $0.1 \mathrm{M}$ phosphate buffer $\left(4^{\circ} \mathrm{C}\right), \mathrm{pH}$ 7.4. The brains were then removed and left at $4^{\circ} \mathrm{C}$ overnight in $30 \%$ sucrose in PBS.

A 1:15 series was cut on the coronal plane through the striatum with a section thickness of $16 \mu \mathrm{m}$. Sections were mounted directly onto slides coated with $0.1 \%$ chrome alum and $1 \%$ gelatin in water and then stored at $-70^{\circ} \mathrm{C}$ until required. Coronal sections $(50 \mu \mathrm{m}$ thick) were cut through the SNpc with one series being mounted onto chrome alum gelatinized slides for counterstaining, and alternate sections were placed freefloating in cryoprotectant for TH immunohistochemistry.

Dopamine transporter immunohistochemistry. Dopamine transporter (DAT) immunohistochemistry was used to label dopaminergic terminals in the caudate putamen $(\mathrm{CPu})$ so that stereological counts could be made of terminal density. The sections were fixed to the gelatinized slides with $10 \%$ neutral buffered formalin $(30 \mathrm{sec})$, rinsed in PBS $(3 \times 10 \mathrm{~min})$, then incubated in blocking solution (PBS, $0.3 \%$ Triton X-100, and 5.0\% normal rabbit serum) for $15 \mathrm{~min}$ followed by a wash in PBS $(1 \times 10 \mathrm{~min})$. The primary antibody rat anti-DAT (Chemicon, Temecula, CA; 1:3000 in PBS, $0.3 \%$ Triton $\mathrm{X}-100$, and $1.0 \%$ normal rabbit serum) was then added to the slides and left overnight at $4^{\circ} \mathrm{C}$. The next day the slides were washed in PBS $(3 \times 10 \mathrm{~min})$, and a biotinylated secondary antibody (rabbit, anti-rat IgG, 1:300; Vector Laboratories, Burlingame, CA) was applied for $2 \mathrm{hr}$ at $4{ }^{\circ} \mathrm{C}$ followed by washes in PBS and incubation in avidin peroxidase for $2 \mathrm{hr}$. These sections were then washed three times in PBS (to remove unbound avidin peroxidase), incubated for $15 \mathrm{~min}$ in intensified cobalt-nickel diaminobenzidine (DAB) (Sigma), and finally hydrogen peroxide $(0.01 \%)$ was added to this solution for a further $5 \mathrm{~min}$ (Adams, 1981; Finkelstein et al., 2000). The sections were then dehydrated through graded alcohol and cleared before being coverslipped using a polystyrene mounting medium.

Tyrosine hydroxylase immunohistochemistry. Tyrosine hydroxylase immunohistochemistry on free-floating sections was used to identify dopaminergic neurons within the SNpc. The $50-\mu \mathrm{m}$-thick sections were washed with PBS $(3 \times 10 \mathrm{~min})$. Blocking solution was then added (PBS, $0.3 \%$ Triton $\mathrm{X}-100$, and $10.0 \%$ normal goat serum) for $15 \mathrm{~min}$, and the sections were then washed in PBS $(10 \mathrm{~min})$. The primary antibody (mouse anti-tyrosine hydroxylase; Boehringer Mannheim, Castle Hill, Australia; $1: 1000$ in PBS, $0.3 \%$ Triton X-100 and 1\% normal goat serum) was added to the wells and left overnight at $4^{\circ} \mathrm{C}$. The next day the sections were rinsed in PBS $(3 \times 5 \mathrm{~min})$ then incubated in biotinylated secondary antibody (biotinylated goat anti-mouse, 1:300; Sigma) for $2 \mathrm{hr}$. Sections were washed in PBS and incubated in avidin peroxidase (1:5000) for $2 \mathrm{hr}$.
Sections were then reacted with cobalt and nickel-intensified DAB. Sections were mounted onto slides using $1 \%$ gelatin, counterstained with $1 \%$ neutral red, dehydrated, and coverslipped.

\section{Fractionator design for estimating total numbers of SNpc} neurons and DAT-immunoreactive varicosities in $\mathrm{CPu}$

The number of neurons in the SNpc and density of DAT-IR varicosities in the $\mathrm{CPu}$ were estimated using a fractionator sampling design (Gundersen et al., 1988; West et al., 1991; Finkelstein et al., 2000). Staining with Neutral Red delineated the area of the SNpc in each section. In each of the sections sampled, SNpc neurons were counted, using the nuclei of stained SNpc cells as the counting unit according to optical dissector rules (Gundersen et al., 1988). For TH immunohistochemistry, labeled profiles were only counted if the first recognizable profile of the cell came into focus within the counting frame (West et al., 1991). Neutral Red or tyrosine hydroxylase counts of SNpc neurons were made on alternate coronal sections. Counts were made at regular predetermined intervals $(x=140 \mu \mathrm{m}, y=140 \mu \mathrm{m})$. These counts were derived by means of a grid program, Stereoinvestigator (MicroBrightField, Colchester, VT), through which a systematic sample of the area occupied by the SNpc was made from a random starting point. An unbiased counting frame of known area $(45 \times$ $35 \mu \mathrm{m}=1575 \mu \mathrm{m}^{2}$ ) was superimposed on the image of the tissue sections viewed under a $100 \times$, numerical aperture (NA) 1.30 oil immersion objective. The entire $z$-dimension of each section was sampled, hence the section thickness sampling fraction was 1 . Counts were taken from 10 sections at a 1:2 interval, extending from the most rostral to the most caudal parts of the SNpc. After all sections from a SNpc were analyzed, the fraction of the area of the sections sampled was calculated (West et al., 1991, 1996). The area sampling fraction is obtained by dividing the area of the counting frame by the area of the distance between sampling regions i.e., $x$ and $y$ intervals. As detailed above, the $x$ and $y$ intervals in sections were both $140 \mu \mathrm{m}$, and the area of the counting frame was $1575 \mu \mathrm{m}^{2}$. Therefore, the area sampling fraction is $1575 /$ $(140 \times 140)=0.0804$. The total number of neurons in the SNpc was estimated by multiplying the number of neurons counted within the sampled regions with the reciprocals of the fraction of the sectional area sampled and the fraction of the section thickness sampled (West et al., 1991; Coggeshall and Lekan, 1996; Finkelstein et al., 2000).

DAT-IR varicosities in the dorsal $400 \mu \mathrm{m}$ of the $\mathrm{CPu}$ were counted from $16-\mu \mathrm{m}$-thick serial sections, at a 1 in 15 series, providing approximately eight sections from each striatum for counting. The dorsal region of $\mathrm{CPu}$ was chosen for sampling because it predominantly receives the SNpc projection (Fallon and Moore, 1978; Bjorklund and Lindvall, 1984; Gerfen et al., 1987), and our previous study demonstrated that sprouting was confined to this region of the striatum (Finkelstein et al., 2000). The striatum was sectioned and examined from its most rostral pole through to the level of the hippocampus heading toward the end of the triangular septal nuclei. Counts of DAT-IR varicosities were made at regular predetermined intervals $(x=170 \mu \mathrm{m}, y=170 \mu \mathrm{m})$. An unbiased counting frame of known area $\left(5 \times 4 \mu \mathrm{m}=20 \mu \mathrm{m}^{2}\right)$ was superimposed on the image of the tissue sections viewed under a $100 \times$, NA 1.30 oil immersion objective. DAT-positive terminals were identified as predominantly round swellings in association with axonal processes. Total terminal numbers (DAT number) were estimated as described for counts of SNpc neurons (above). The coefficients of error (CE) and coefficients of variance $(\mathrm{CV})$ were calculated as estimates of precision, and values of $<0.1$ were accepted (Braendgaard et al., 1990; West and Gundersen, 1990; West et al., 1991). Density of DAT-IR varicosities and the number of varicosities per neuron were calculated.

\section{Determination of striatal dopamine levels}

Dopamine levels in the dorsal striatum of D1 and D2 adult mutant mice were determined using HPLC. Mice were killed by cervical dislocation, and their brains were rapidly removed and frozen. The $\mathrm{CPu}$ was dissected out and weighed. The dissected striatal tissue was placed in $200 \mu \mathrm{l}$ of $4 \mathrm{M}$ perchloric acid $\left(\mathrm{HClO}_{4}\right)$ containing $0.15 \%$ sodium metabisulphate $\left(\mathrm{Na}_{2} \mathrm{~S}_{2} \mathrm{O}_{5}\right)$ and $0.05 \%$ disodium EDTA as well as the internal standard, $0.01 \%$ dihydroxybenzylamine (DHBA).

The sample tissue was then homogenized, and cellular and vesicular membranes were disrupted using a sonicator. The samples were stored at $-70^{\circ} \mathrm{C}$ and centrifuged on the day of analysis. The samples were analyzed by ion exchange HPLC. The HPLC was coupled to an LC-4A amphometric detector and the height of the peaks was recorded using a chart recorder with peak heights determined manually (Herges and Taylor, 1999). 


\begin{tabular}{|c|c|c|c|c|c|c|c|}
\hline Genotype & SNpc counts ${ }^{a}$ & $\begin{array}{l}\text { Percentage } \\
\text { of change }^{b}\end{array}$ & TH-IR neurons ${ }^{c}$ & $\begin{array}{l}\text { Volume of } \\
\text { CPU }\left(\mathrm{cm}^{3}\right)\end{array}$ & $\begin{array}{l}\text { DAT-IR terminal } \\
\text { density }^{d}\end{array}$ & $\begin{array}{l}\text { Percentage of } \\
\text { change }^{b}\end{array}$ & $\mathrm{NTT}^{e}$ \\
\hline $\mathrm{D} 1(+/+)$ & $\begin{array}{l}6130 \pm 498 \\
(n=18)\end{array}$ & - & $\begin{aligned} 5373 & \pm 464 \\
p & =87.7 \%\end{aligned}$ & - & - & - & - \\
\hline $\mathrm{D} 2(+/+)$ & $\begin{array}{l}5971 \pm 508 \\
(n=28)\end{array}$ & - & $\begin{aligned} 5566 & \pm 430 \\
p & =93.2 \%\end{aligned}$ & - & - & - & - \\
\hline All $(+/+)$ & $\begin{array}{l}6001 \pm 508 \\
(n=46)\end{array}$ & 0 & $\begin{aligned} 5462 & \pm 429 \\
p & =90.1 \%\end{aligned}$ & 5.29 & $\begin{array}{l}1.22 \times 10^{-2} \pm \\
0.17 \times 10^{-2}\end{array}$ & 0 & $2.23 \times 10^{-6}$ \\
\hline $\mathrm{D} 1(+/-)$ & $\begin{array}{l}5522 \pm 210^{*} \\
(n=15)\end{array}$ & $-8.0 \%$ & $\begin{aligned} 3711 & \pm 431 * \\
p & =67.4 \%\end{aligned}$ & - & $\begin{array}{l}1.15 \times 10^{-2} \pm \\
0.07 \times 10^{-2}\end{array}$ & $-5.7 \%$ & $2.08 \times 10^{-6}$ \\
\hline $\mathrm{D} 2(+/-)$ & $\begin{array}{l}5638 \pm 578^{*} \\
(n=21)\end{array}$ & $-6.1 \%$ & $\begin{aligned} 4145 & \pm 288^{*} \\
p & =79.1 \%\end{aligned}$ & - & $\begin{array}{l}1.61 \times 10^{-2} \pm \\
0.21 \times 10^{-2 *}\end{array}$ & $31.2 \%$ & $2.86 \times 10^{-6 *}$ \\
\hline $\mathrm{D} 1(-/-)$ & $\begin{array}{l}4871 \pm 361^{*} \\
(n=12)\end{array}$ & $-18.8 \%$ & $\begin{aligned} 3711 & \pm 431^{*} \\
p & =64.3 \%\end{aligned}$ & 3.72 & $\begin{array}{l}1.14 \times 10^{-2} \pm \\
0.11 \times 10^{-2 *}\end{array}$ & $-6.6 \%$ & $3.50 \times 10^{-6 *}$ \\
\hline $\mathrm{D} 2(-/-)$ & $\begin{array}{l}4650 \pm 526^{*} \\
(n=16)\end{array}$ & $-21.7 \%$ & $\begin{aligned} 3480 & \pm 352 * \\
p & =77.3 \%\end{aligned}$ & 5.20 & $\begin{array}{l}2.12 \times 10^{-2} \pm \\
0.13 \times 10^{-2 *}\end{array}$ & $73.8 \%$ & $6.11 \times 10^{-6 *}$ \\
\hline
\end{tabular}

${ }^{a}$ Mean $\pm \mathrm{SD} ; n=$ number of hemispheres.

${ }^{b}$ Percentage of change over Wt.

${ }^{c}$ Mean $\pm \mathrm{SD} ; p=$ percentage of total SNpc cells.

${ }^{d}$ Mean density of DAT-IR terminals $/ \mu \mathrm{m}^{3} \pm \mathrm{SD}$.

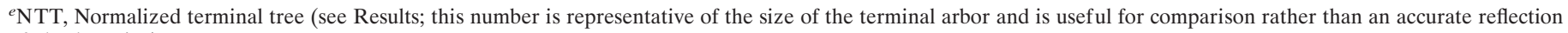
of absolute size).

*Significantly different from Wt.

The mobile phase consisted of $8 \% \mathrm{v} / \mathrm{v}$ methanol in purified deionized water containing $14.2 \mathrm{gm}$ of trichloroacetic acid, $0.25 \mathrm{gm}$ of EDTA, and $3.2 \mathrm{gm}$ of sodium hydroxide. After adjusting the $\mathrm{pH}$ of the mobile phase to $\mathrm{pH} 2.8$ (using $5 \mathrm{M}$ sodium hydroxide), the final solution was filtered through a $0.45 \mu \mathrm{m}$ Durapore membrane filter (Waters, a division of Millipore, Bedford, MA) and degassed using a vacuum pump (Herges and Taylor, 1999). For every chromatograph run, a standard curve of dopamine $(0.1-2.0 \mu \mathrm{g})$ with DHBA as the internal standard was established, and precision, accuracy, and recovery were determined. The dopamine standards were prepared fresh before each chromatograph analysis. The internal standard (DHBA, $0.1 \mathrm{mg} / \mathrm{ml}$ ) was added to each dopamine standard solution. The dopamine content of the samples was calculated from the ratios of the peak heights of dopamine to the internal standard, DHBA. The dihydroxphenylacetic acid (DOPAC) content of the sample was also calculated as the ratio of the peak height of DOPAC and the internal standard. DA activity was expressed as the concentration of DOPAC to DA, [DOPAC]/[DA].

\section{Drug treatment groups}

The reversible dopamine receptor antagonist haloperidol $(2.5 \mathrm{mg} / \mathrm{kg}$; Serenace, Searle Laboratories, Australia) was administered to animals in drinking water continuously for 2 months. The irreversible receptor antagonist EEDQ (Sigma) was dissolved in 50\% ethanol then diluted with $0.9 \%$ saline to an ethanol concentration of $5 \%$, and $6 \mathrm{mg} / \mathrm{kg}$ was injected intraperitoneally every third day for a period of 2 months.

\section{Lesioning}

A partial lesion of the SNpc was produced in the mice by injecting the neurotoxin 6-OHDA into the right SNpc. Mice were anesthetized with $4 \%$ chloral hydrate in PBS $(10 \mathrm{ml} / \mathrm{kg}$, i.p. $)$, and heads were secured in a stereotaxic head frame with the bite bar $3 \mathrm{~mm}$ above horizontal. A 1.5 $\mu \mathrm{g} / \mu \mathrm{l}$ solution of 6-OHDA was prepared with ascorbic acid $(0.2 \mathrm{mg} / \mathrm{ml})$ and kept on ice until the time of injection. A $10 \mu \mathrm{l}$ Hamilton syringe (with a 26 gauge needle) mounted in a syringe pump (Cole-Parmer, Vernon Hills, IL) was inserted into the right SNpc through a small hole drilled through the top of the skull. A single injection $(2.5 \mu \mathrm{g})$ of 6-OHDA (Sigma) was made into the right SNpc (anteroposterior, 3.0 $\mathrm{mm}$; lateral, $1.05 \mathrm{~mm}$; dorsoventral, $4.7 \mathrm{~mm}$, with respect to lambda) (Franklin and Paxinos, 1997). On completion of the injection, the needle was left in place for $5 \mathrm{~min}$ then slowly withdrawn at a rate of $1 \mathrm{~mm} / \mathrm{min}$. After surgery, the skin was sutured, antiseptic (1\% w/w iodine, Betadine; Faulding and Company, Salisbury, South Australia) was applied to the wound, and the mice were left in a warmed cage to recover. Paracetamol
$(100 \mathrm{mg} / \mathrm{kg})$ was administered in drinking water as an analgesic after surgery.

\section{RESULTS}

$\mathrm{SNpc}$ neurons and DAT-positive terminals in the striatum were counted in $\mathrm{Wt}, \mathrm{D} 1(-/-), \mathrm{D} 1(+/-), \mathrm{D} 2(+/-)$, and D2(-/-) mice to calculate the size of the terminal arbors of SNpc neurons. Counts were also obtained on the pharmacologically manipulated as well as lesioned animals to assess their ability to regulate terminal arbor size. ANOVAs with Tukey post hoc tests were used with statistical differences set at the level of $p<0.05$.

\section{Morphology of the nigrostriatal pathway in D1 and D2 receptor knock-out mice}

Stereology of the substantia nigra pars compacta

$\mathrm{SNpc}$ neurons were counted in Wt, D1(-/-), D1(+/-), D2 $(+/-)$, and D2 $(-/-)$ animals (Table 1). Staining with Neutral Red delineated the area of the SNpc in each section. The SNpc was recognized as the sheet of densely packed neurons of $\sim 16 \mu \mathrm{m}$ in soma size. The ventral margin of the SNpc was distinguished from the substantia nigra pars reticulata neurons, the somata being larger $(\sim 20 \mu \mathrm{m})$ and less densely packed than those in the SNpc. Lying rostromedially to SNpc was the ventral tegmental area, which was distinguished from the SNpc by its smaller (13 $\mu \mathrm{m})$ and less densely packed cells. Caudally, the medial border of the SNpc abutted the medial lemniscus, which contained loosely scattered neurons (Nelson et al., 1996).

No significant difference was seen in the number of $\mathrm{SNpc}$ neurons in the two groups of $\mathrm{Wt}$ mice (D1+/+ and D2+/+) hence, the results from these mice were pooled in subsequent analyses. In both D1 and D2 receptor knock-out mice, the number of neurons in the SNpc was significantly less (19 and 22\%, respectively) than in the Wt controls (Table 1 , Figs. $1 A, 2 B$.) The $\mathrm{CE}$ for SNpc counts for these animals ranged from 0.018 to 0.097 and a CV was between 0.02 and 0.89 , indicating an accurate 


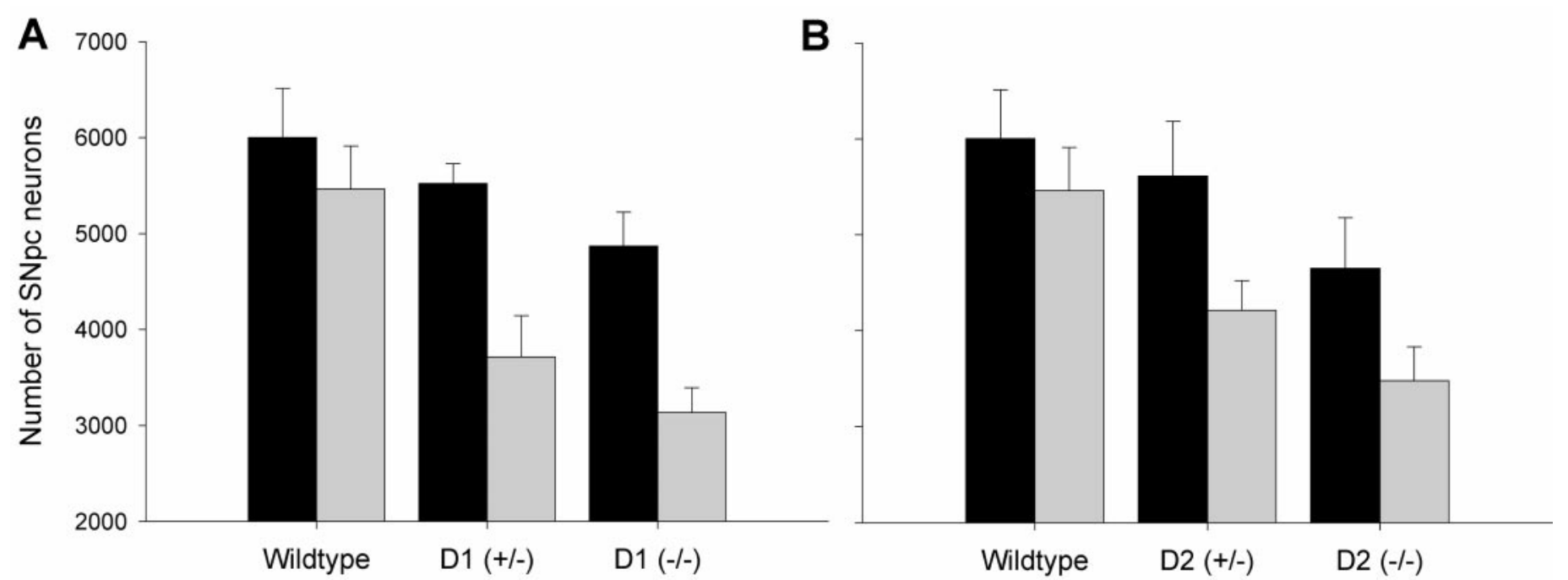

Figure 1. Histograms showing the number of neurons counted in the SNpc (mean $\pm \mathrm{SD}$ ) of D1 dopamine receptor mutants $(A)$ and $\mathrm{D} 2$ dopamine receptor mutants $(B)$. Counts of SNpc neurons stained with Neutral Red are shown in black, and TH-IR counts are shown in gray. A, D1( $-/-)$ have significantly fewer (19\%) Neutral Red-stained cells and $43 \%$ fewer TH-IR cells than Wt mice. Counts in heterozygous mice were intermediate between Wt and D1 $(-/-)$ and significantly different to both. B. Similarly, counts of Neutral Red-stained cells and TH-IR cells are reduced (23 and $36 \%$, respectively) in D2(-/-) compared with Wt and with heterozygous counts intermediate between those seen in the D2(-/-) and Wt.
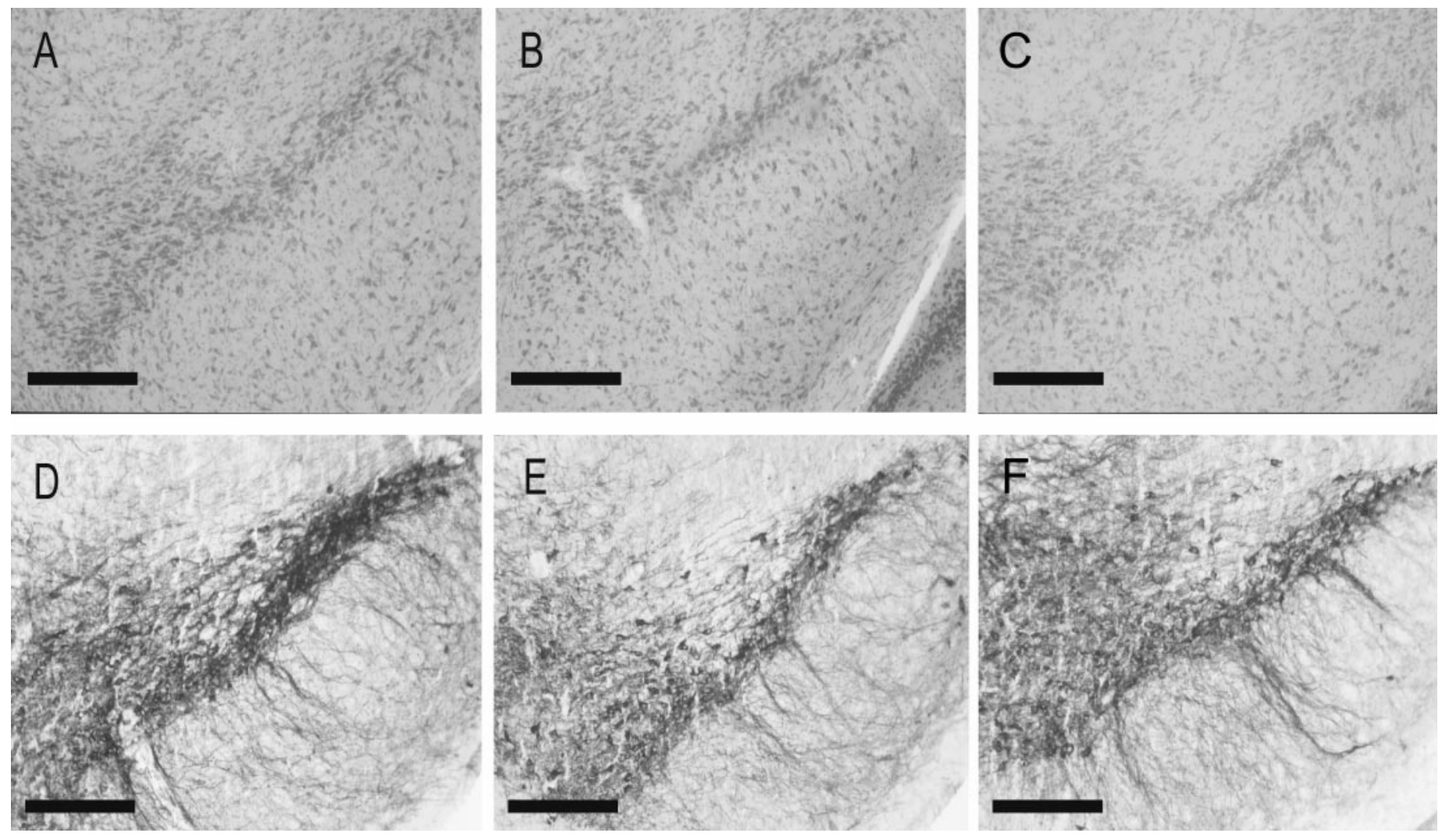

Figure 2. A-C are photomicrographs showing Neutral Red staining through the middle to rostral portion of SNpc in Wt, D1(-/-), and D2(-/-) mice, respectively. $D-F$ are photomicrographs of TH-IR SNpc neurons. Note the significant reduction in the counts of SNpc neurons in the receptor knock-out mice compared with Wt. Scale bars, $250 \mu \mathrm{m}$.

sampling protocol. In these same animals, tyrosine hydroxylasepositive SNpc neurons were counted in alternate sections to those in which Neutral Red SNpc cells were counted. As expected, the majority (90\%) of neurons in the SNpc of Wt mice were TH-IR (Table 1). In both D1 and D2 receptor knock-out mice however, the proportion of TH-IR neurons was significantly reduced (64 and $77 \%$ of total SNpc neurons respectively) (Table 1, Figs. 1, 2). Counts of Neutral Red and tyrosine hydroxylase-stained SNpc neurons in heterozygous mice were intermediate between those of the Wt and receptor knock-out mice (Fig. 1, Table 1). 


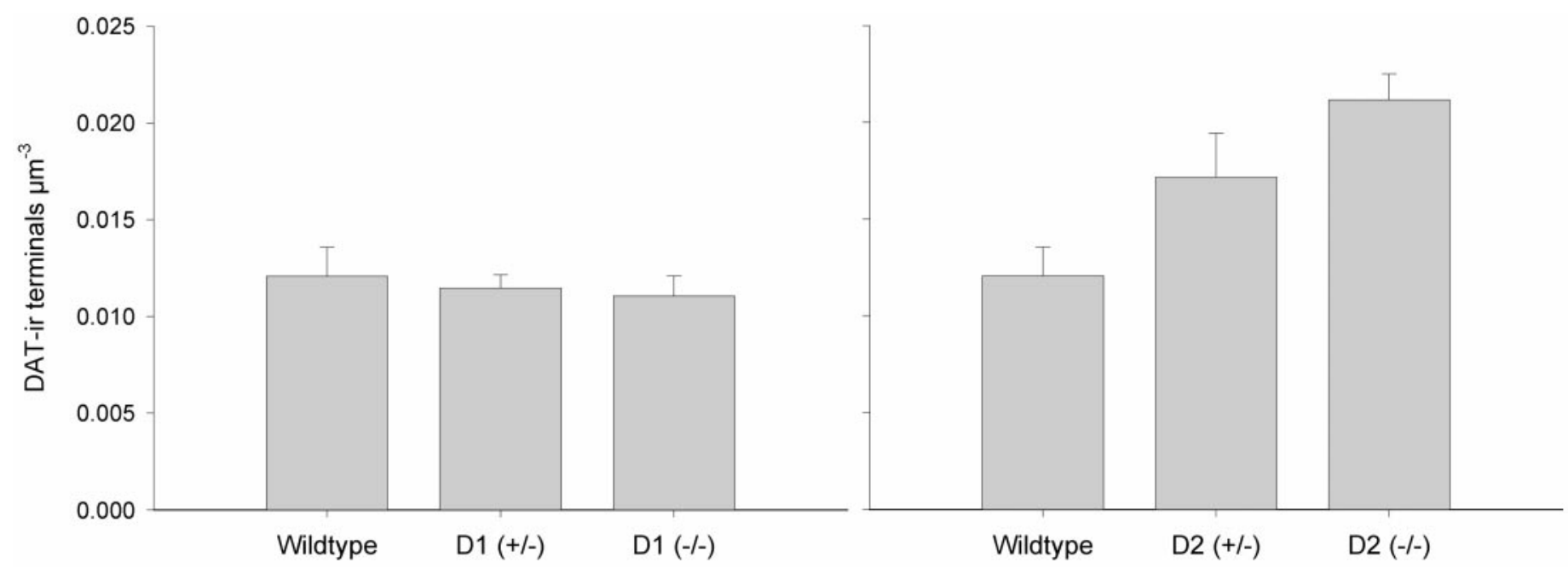

Figure 3. Histograms of estimates of DAT-IR terminal density in the dorsal CPu of D1(-/-) mice $(A)$ and $\mathrm{D} 2(-/-)$ mice $(B)$. $A$, There is no significant difference between terminal densities of $\mathrm{Wt}, \mathrm{D}(+/-)$, and $\mathrm{D} 1(-/-)$ mice. $B$, The density of terminals in the dorsal $\mathrm{CPu}$ of $\mathrm{D} 2(-/-)$ is significantly greater than in Wt mice, with heterozygous animals having intermediate densities.

\section{Stereology of DAT-labeled varicosities}

Striatal tissue was processed for DAT immunohistochemistry, and counts of varicosities were estimated stereologically as described in Materials and Methods (see Fig. 5). Density was determined as the number of varicosities estimated within the chosen counting area. DAT-IR varicosities and terminals were uniformly distributed within the dorsal striatum. The density of varicosities in the $\mathrm{CPu}$ of $\mathrm{D} 1(-/-)$ mice was normal, whereas in $\mathrm{D} 2(-/-)$ mice it was significantly greater than in $\mathrm{Wt}$ and D1(-/-) animals (74\% increase) (Fig. 3, Table 1).

We wished to derive a representation of the average size of the terminal arbor of SNpc neurons for each genotype. The only way to measure the actual size of the arbor is to anterogradely fill and reconstruct individual axons, which is time-consuming and laborintensive. Because of these constraints only a small sample of the neuronal population can be analyzed. Ideally, arbor size could be obtained by dividing the total number of DAT-IR terminals in the dorsal $\mathrm{CPu}$ (obtained by multiplying DAT-IR density by volume of dorsal $\mathrm{CPu}$ ) by the actual number of TH-IR neurons counted in the SNpc. However, the precise volume of the dorsal tier innervated by SNpc neurons cannot be delineated and furthermore, the volume of the $\mathrm{CPu}$ varies according to the genotype. Previously we have devised a method for comparing arbor size after different treatments by dividing terminal density by the number of SNpc neurons (Finkelstein et al., 2000). However, this method assumes that the volume of the $\mathrm{CPu}$ volume and hence the volume of the dorsal tier innervated by SNpc neurons is the same in all groups. Because the volume of the $\mathrm{CPu}$ in the $\mathrm{D} 1(-/-)$ mice is significantly less than D2(-/-) and Wt mice (Table 1), this method is not suitable for this study. We therefore devised a new method for determining arbor size, which takes into consideration varying striatal volumes. We can estimate the total volume of the $\mathrm{CPu}(\mathrm{VCPu})$, and we have assumed that the proportion of the $\mathrm{CPu}$ volume innervated by $\mathrm{SNpc}$ neurons is the same in all genotypes. Dividing VCPu by the number of SNpc provides a figure that is proportional to the average size of the terminal tree of an individual SNpc neuron in a particular genotype and provides a means for comparing the extent of branching across genotypes. Because this number was obtained from the whole volume of the $\mathrm{CPu}$ (rather than the dorsal tier), it is

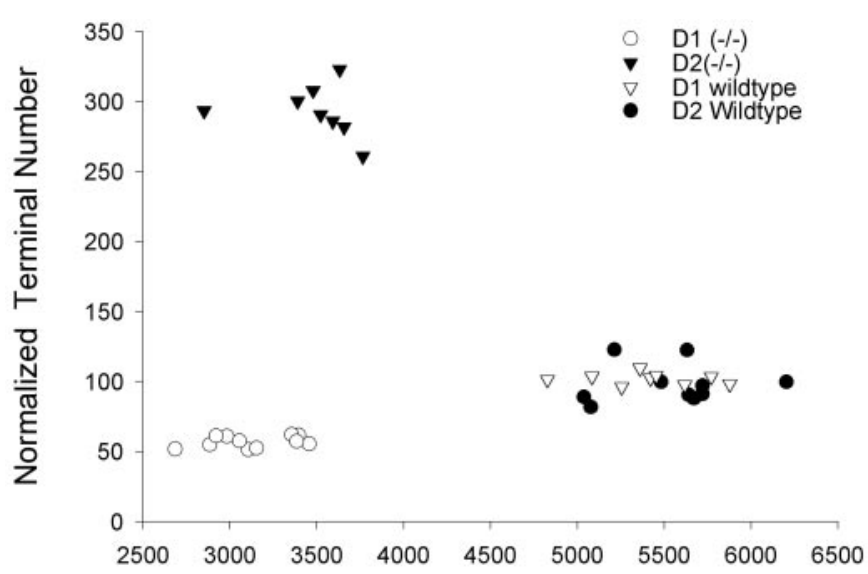

Number of TH-ir SNpc Neurons

Figure 4. A plot of normalized number of DAT-IR terminals in the dorsal striatum plotted against number of neurons in the SNpc. The number of DAT terminals in the dorsal striatum of D1 $(-/-)$ mice (open circles) was approximately half of that observed in Wts ( filled circles and open triangles). However, D1(-/-) mice had reduced numbers of SNpc neurons and consequently, larger terminal trees (Table 1). In the case of D2 $(-/-)$ mice (closed triangle), the normalized terminal number in the dorsal striatum was three times normal despite a significant reduction in the number of SNpc neurons.

proportional to rather than a precise indication of the size of the terminal arbor and may result in an overestimation of the terminal tree size. First, we obtained a normalized representation of the number of terminals (NTN) in the dorsal CPu (Fig. 4) using the formula:

$$
N T N_{\text {genotype }}=\mathrm{DT}_{\text {genotype }} \times \mathrm{VCPu}_{\text {genotype }} / \mathrm{DT}_{\text {wild-type }} \times \mathrm{VCP}_{\text {wild-type }},
$$

where DT = density of terminals in the dorsal $\mathrm{CPu}$, and subscript refers to the relevant genotype. In Figure 4 this value was plotted against the number of TH-IR SNpc neurons in each animal. However, the size of the average terminal tree can be determined by dividing the terminal number by the number of SNpc. Hence, terminal tree size (TT) is the number of DAT terminals (DT) 


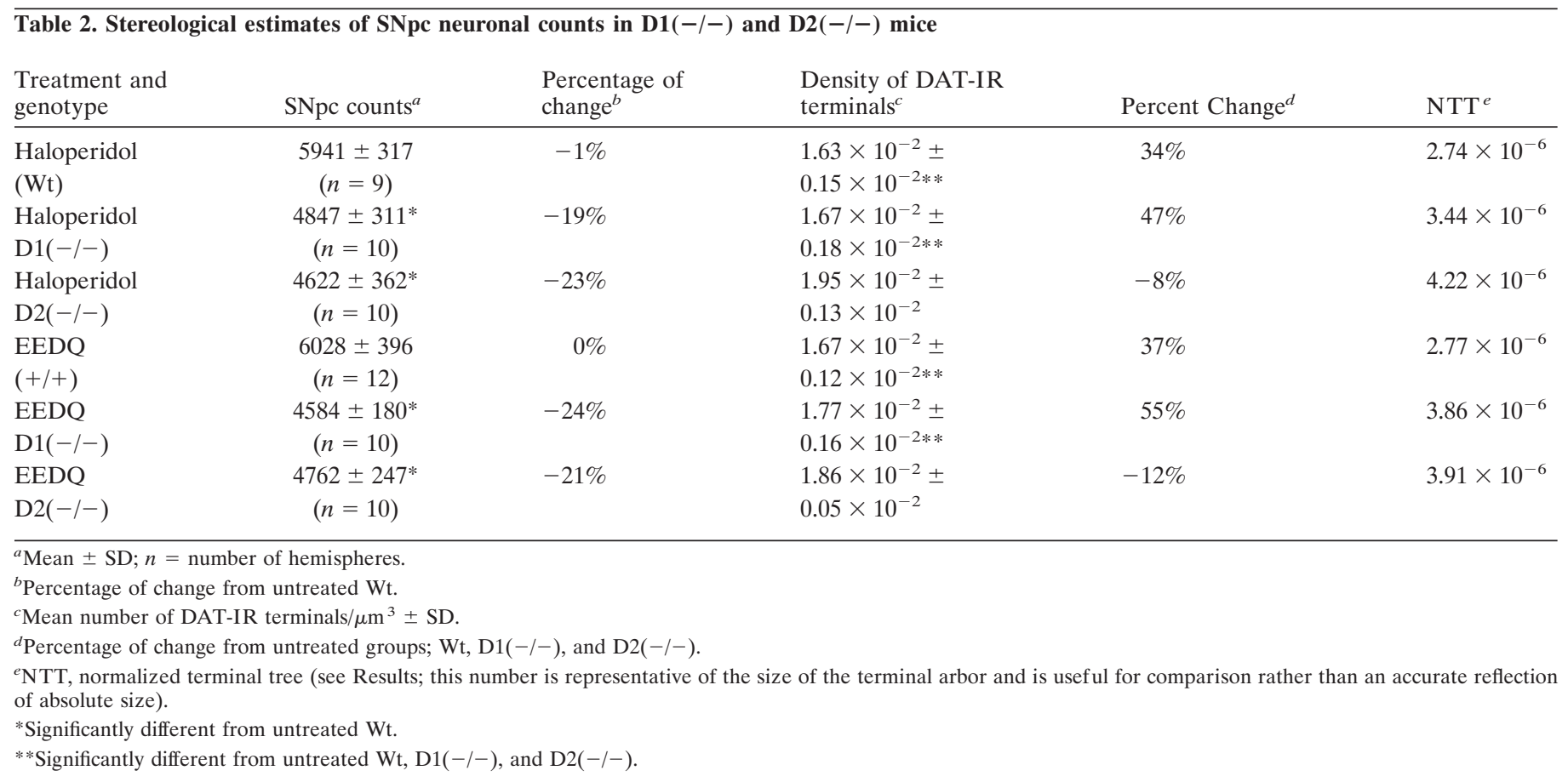

multiplied by $\mathrm{CPu}$ volume (VCPu) divided by the number of $\mathrm{SNpc}$ neurons (NSNpc), for any given genotype neurons (Tables $1,2)$.

$$
T T_{\text {genotype }}=\left(\mathrm{DT}_{\text {genotype }} \times \mathrm{VCPu}_{\text {genotype }}\right) / \mathrm{NSNpc}_{\text {genotype }}
$$

For the purpose of comparison a normalized terminal tree (NTT) was calculated using the terminal tree size of $\mathrm{Wt}$ as the standard:

$$
N T T_{\text {genotype }}=\mathrm{TT}_{\text {genotype }} / \mathrm{TT}_{\mathrm{Wt}} \times 100(\text { Tables1,2). }
$$

Although the density of varicosities in the CPu of D1(-/-) mice was normal, the number of TH-IR SNpc neurons and volume of $\mathrm{CPu}$ was reduced (Fig. 1) so that the NTT of SNpc neurons in the D1 $(-/-)$ animals was in fact, larger than in the Wt mice (Table 1).

The density of varicosities in the $\mathrm{CPu}$ of $\mathrm{D} 2(-/-)$ mice was significantly greater than in $\mathrm{Wt}$ and $\mathrm{D} 1(-/-)$ animals $(74 \%$ increase) (Figs. 3, 5, Table 1). Because of this (and the reduced number of TH-IR SNpc neurons in D2 $(-/-)$ mice), the NTT of TH-IR SNpc neurons in the D2(-/-) mice were $~ 300 \%$ larger than in the Wt controls. The counts from D2 $(+/-)$ mice were intermediate between those of the $\mathrm{Wt}$ and $\mathrm{D} 2(-/-)$ mice.

\section{Determination of striatal dopamine activity}

Basal levels of dopamine and DOPAC in the dorsal striatum of $\mathrm{Wt}, \mathrm{D} 1(+/-), \mathrm{D} 1(-/-), \mathrm{D} 2(+/-)$, and D2(-/-) mice were determined and expressed as amount of dopamine or DOPAC per gram of $\mathrm{CPu}$ tissue and dopamine activity, expressed as the ratio of DOPAC per dopamine. Although dopamine levels in the striatum of $\mathrm{D} 2(-/-), \mathrm{D} 2(+/-)$, and $\mathrm{D} 1(+/-)(n=6,7$, and 11 , respectively) were not significantly different from controls $(n=19)$ (Fig. $6 A, B)$, dopamine levels in D1 $(-/-)$ mice $(n=6)$ were significantly greater $(33 \%)$ than in $\mathrm{Wt}$ mice. However, both DOPAC levels and dopamine activity were significantly reduced in the $\mathrm{D} 1(-/-)$ mice $(n=6)$ compared with wild-types $(n=12)$, suggesting increased dopamine stor- age and decreased turnover in the dopaminergic terminals of these animals (Fig. 6A-C).

Conversely, dopamine levels were normal in the D2 $(-/-)$ mice, whereas there was a statistically significant increase in DOPAC levels and dopamine activity $(n=3)$. Together, this implies normal dopamine storage but a high dopamine turnover (Fig. 6).

Dopamine activity per terminal was calculated by dividing each measure by the density of DAT-IR terminals. Although D2 (-/-) mice had normal striatal dopamine levels, dopamine activity per terminal was markedly increased (Fig. 6D). In contrast, striatal dopamine levels in D1(-/-) mice were elevated, yet dopamine activity was sixfold less than Wt mice (Fig. 6D).

\section{Effects of dopamine receptor antagonists on D1 and D2 receptor knock-out mice}

In haloperidol-treated Wt mice, DAT terminal density was $34 \%$ greater than in untreated Wt mice and $37 \%$ greater in EEDQtreated mice than untreated Wt mice (Table 2). Terminal density also increased in D1 $(-/-)$ mice after treatment with haloperidol $(46 \%)$ and EEDQ (55\%) (Table 2). In contrast, there was no significant change in terminal density of D2(-/-) mice after treatment with either antagonist (Fig. 7).

\section{Effects of 6-OHDA lesioning of the SNpc in D1 and D2 receptor knock-out mice}

A small dose of the neurotoxin 6-OHDA was injected into the right $\mathrm{SNpc}$ of $\mathrm{Wt}, \mathrm{D} 1(-/-)$, and $\mathrm{D} 2(-/-)$ mice to produce a partial lesion. Animals were allowed to recover over 2 months, and the number of SNpc neurons as well as DAT-IR varicosities in the dorsal $\mathrm{CPu}$ were counted and density was calculated. An index of the terminal tree (TT) size was made (as above), and an NTT was calculated. In total, $17 \mathrm{Wt}(+/+), 14 \mathrm{D} 1(-/-)$, and 13 $\mathrm{D} 2(-/-)$ mice received partial lesions of their right SNpc. Stereological estimates of SNpc neuron numbers confirmed that a variety of lesion sizes were created, ranging from 2 to $83 \%$. In 


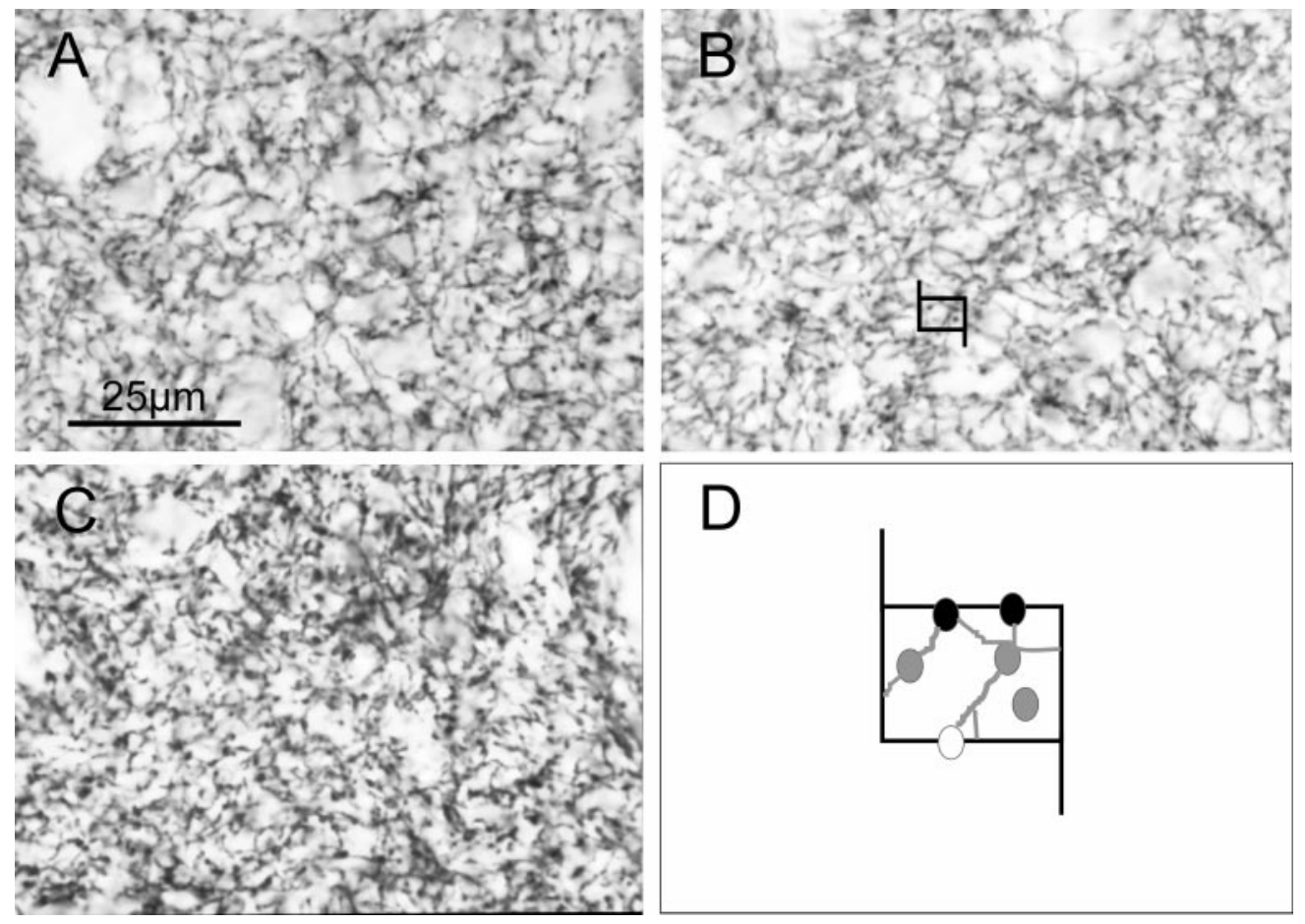

Figure 5. Photomicrographs of DATIR varicosities in the dorsal $\mathrm{CPu}$ of Wt, D1 $(-/-)$, and D2 $(-/-)$ mice $(A-C$, respectively). Note the similarity in density of DAT-IR in Wt and D1(-/-) mice, whereas the increased density of DAT-IR varicosities in the D2(-/-) mice. $D$ shows a diagram of the counting frame seen in $B$. Here, five varicosities were counted in total and include the gray varicosities within the frame as well as the black varicosities that lie on the inclusion lines. The white varicosity was not counted because it lay on an exclusion line. Scale bar, $25 \mu \mathrm{m}$. some animals, the number of neurons in the contralateral SNpc was reduced, presumably because of diffusion of the toxin. In these cases, the contralateral hemisphere was included as an example of a small lesion size.

As shown previously in rats (Finkelstein et al., 2000), our estimates of DAT-IR terminal density showed that Wt mice were able to maintain terminal density within a normal range until $>75 \%$ of SNpc neurons were lost. D1 (-/-) mice also maintained normal terminal density in the $\mathrm{CPu}$ until $\sim 75 \%$ of $\mathrm{SNpc}$ neurons was destroyed (Figs. $8 A, 9 B)$. In contrast, in D2(-/-) mice, terminal density was reduced linearly in proportion to the lesion size. After a $40 \%$ lesion, terminal density fell by $\sim 50 \%$ of nonlesioned values in D2(-/-) mice and by $\sim 100 \%$ after lesions of $\geq 75 \%$ (Figs. $8 B, 9 C$ ). After lesions of wild-type and D1 $(-/-$ ) mice, there was no change in distribution of terminals or density of terminals. However, there was clear reduction in density of terminals in the dorsal striatum after lesions of the D2(-/-), compared with ventral striatum. In all genotypes, terminals were again predominantly found in the matrix region innervated by the dorsal SNpc. In the lesioned animals, the SNpc cell loss was more pronounced around the site of the injection. There was, however, no visible unevenness of terminals within the dorsal striatum of Wt or D1 mice. After larger lesions in D2 $(-/-)$, terminal density was unevenly distributed with areas showing no terminals, whereas other regions contained small clusters of varicosities.

\section{DISCUSSION}

This study demonstrates the role of the D1R and D2R in modulating the size of the striatal terminal arbor of SNpc neurons and in regulating steady-state striatal DA levels.

In both D1 $(-/-)$ and D2(-/-) mice the number of SNpc neurons was reduced. Nevertheless, in both genotypes the size of the terminal tree of $\mathrm{SNpc}$ neurons is greater than in $\mathrm{Wt}$ mice, the increase being more pronounced in $\mathrm{D} 2(-/-)$. The increase in terminal arbor size in D2 $(-/-)$ mice and increased DA activity is consistent with the hypothesis that the D2 autoreceptor acts to regulate the delivery of DA. Our findings suggest that this regulation is not confined to DA storage, synthesis, and turnover in the terminals but is also manifest in the density of DA terminals.

Released dopamine is converted to DOPAC after reuptake into the nerve terminal and into homovanillic acid at extraneuronal sites. DOPAC however, is the major dopamine metabolite in rodent brains and, levels in the striatum reflect the activity of dopaminergic neurones within the nigrostriatal pathway (Cooper et al., 1996). Dopamine activity, expressed as a ratio of DOPAC and dopamine is independent of tissue weight, thereby yielding a reliable index. Using these measures, dopamine activity in the D2(-/-) mice was high, despite normal dopamine levels. This suggests impaired regulation of dopamine storage and release, as might be expected when D2 autoreceptor function is not present (Cooper et al., 1996). In contrast, D1(-/-) mice have high levels of dopamine but low dopamine activity, suggesting that in these animals dopamine levels reflect storage within terminals with reduced transmitter release. This suggests augmented D2 function in D1 mutants. A direct mechanism seems unlikely, because the D1 receptor is not expressed presynaptically. However, a compensatory increase in D2 levels seen in the D1(-/-) mice (data not shown) may underlie the augmented D2 function. Either transynaptic signaling or some "long loop" signaling through striatal projections onto $\mathrm{SNpc}$ cell bodies may also contribute.

In a previous study in rats we reconstructed individual axons and demonstrated that after lesions, axonal arbors were larger (Finkelstein et al., 2000). This increase was related to the extent of the lesion. In that study we developed the method for estimating neuronal arbor size by estimating terminal density and dividing this by the number of SNpc neurons. This was found to correlate well with reconstructed arbor size, and a similar method has been used in this current study. In that study, striatal volumes were the same in each animal, reducing the assumptions and arithmetic corrections necessary in the present study. Neverthe- 

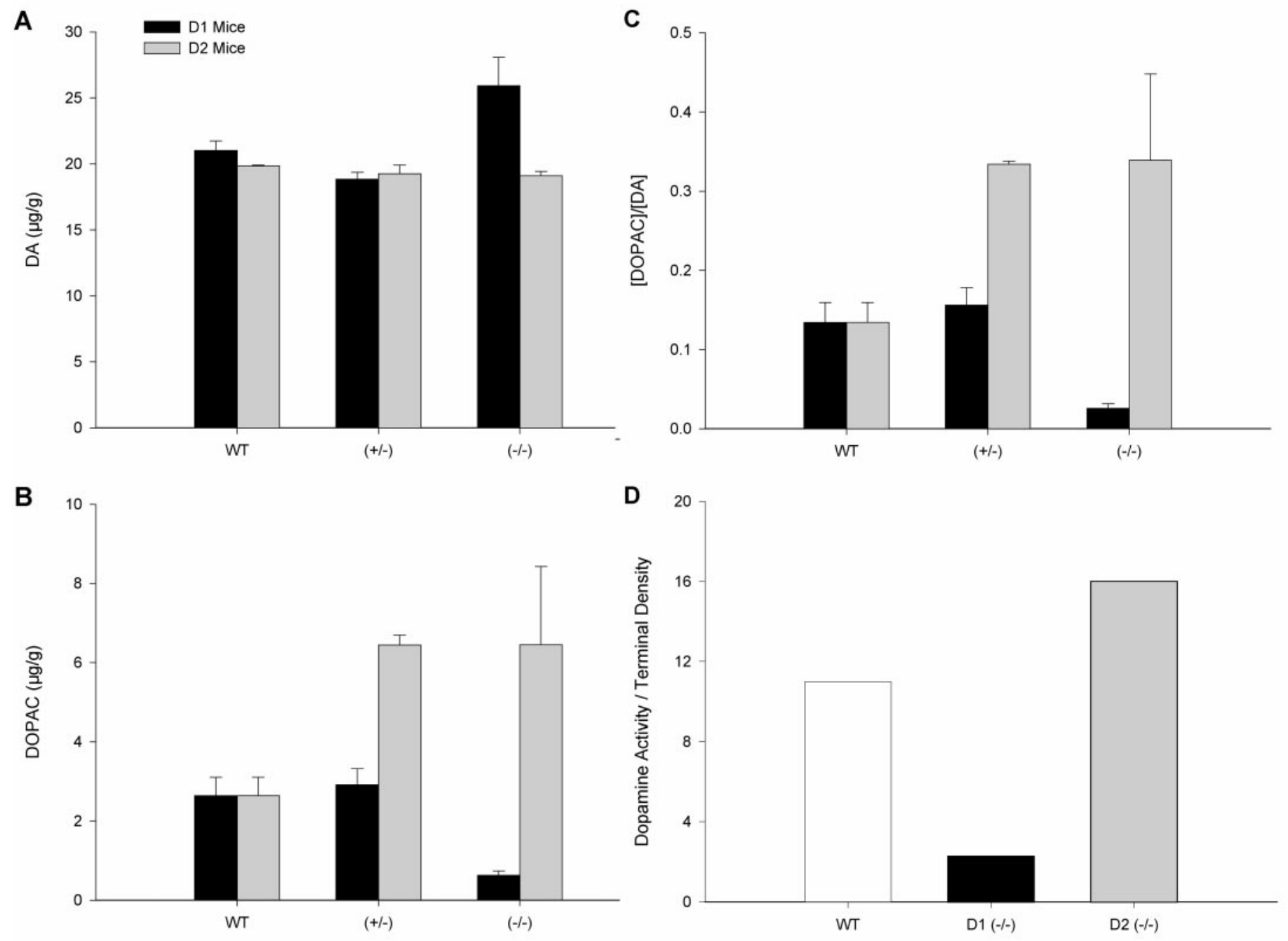

Figure 6. Dopamine and DOPAC concentrations (mean $\pm \mathrm{SD})$ in the CPu of D1(-/-) mice and D2(-/-) mice $(A, B$, respectively). Dopamine concentration is significantly greater in D1 $(-/-)$ mice than in wild types, whereas there was no difference between dopamine concentration in D2(-/ $)$ mice and Wts. DOPAC levels were decreased in D1 $(-/-)$ mice, whereas DOPAC levels were elevated in D2 $(-/-)(B)$. Dopamine activity was reduced in the D1 $(-/-)$ and increased in the D2 $(-/-)$ mice $(C)$. $D$ shows a plot of the level of dopamine activity per SNpc terminal in the striatum of Wt, D1 $(-/-)$, and D2 $(-/-)$ mice (calculated by dividing DA activity by terminal density). In the D1 $(-/-)$ mice, dopamine activity per terminal were reduced, whereas they were significantly increased in $\mathrm{D} 2(-/-)$ mice.

less, the concordance between the two studies is reassuring. In rats we found that terminal density was maintained within the normal range until the number of $\mathrm{SNpc}$ neurons were reduced by $\sim 80 \%$. We confirmed this observation in $\mathrm{Wt}$ and $\mathrm{D} 1(-/-)$ mice. In both groups, terminal density was normal until $\sim 75 \%$ of $\mathrm{SNpc}$ neurons were destroyed. The size of the terminal arbors must have progressively increased in both $\mathrm{Wt}$ and D1(-/-) mice, until lesions reached $\sim 75 \%$, beyond this point remaining neurons could compensate no further, hence the decreased density. The findings were quite different in the D2 $(-/-)$ mice. Terminal density was abnormally high in these animals and did not increase, even after EEDQ and haloperidol, which increased terminal density in Wt and D1 $(-/-)$ mice. After lesions in D2(-/-) mice, terminal density progressively fell in proportion to the size of the lesion, suggesting that the size of the terminal arbor did not increase to compensate for the effect of the lesion.

To explain these findings, we conclude that the D2R must play a role in regulating terminal density. In Wt and D1 $(-/-)$ mice, terminal density is at normal levels, and blockade of D2R results in an increase in terminal density and size of terminal arbor. The lack of effect of haloperidol and EEDQ on D2(-/-) mice suggests that when affecting terminal tree size, these agents are acting through the $\mathrm{D} 2 \mathrm{R}$ rather than other DA receptors. The results also suggest that during development, lack of D2R results in unchecked branching of DA terminals. Further stimulus to sprout through lesioning cannot elicit a compensatory response, presumably because maximal sprouting has already occurred in these animals. The extensive sprouting of SNpc neurons in the striatum of D2(-/-) mice is not readily explained by the neurotrophic hypothesis, because glial cell-derived neurotrophic factor levels are reduced, and levels of brain derived neurotrophic factor and neurotrophin-3 are unchanged in their striatum (Bozzi and Borrelli, 1999).

The dopamine D2 receptor exists in two forms; as an autoreceptor present on the presynaptic cell and as a postsynaptic receptor (Creese, 1982; Kandel et al., 1991; Usiello et al., 2000). Because D2(-/-) mice used in this study have both isoforms ablated, the identity of the specific D2R involved in the regulation 


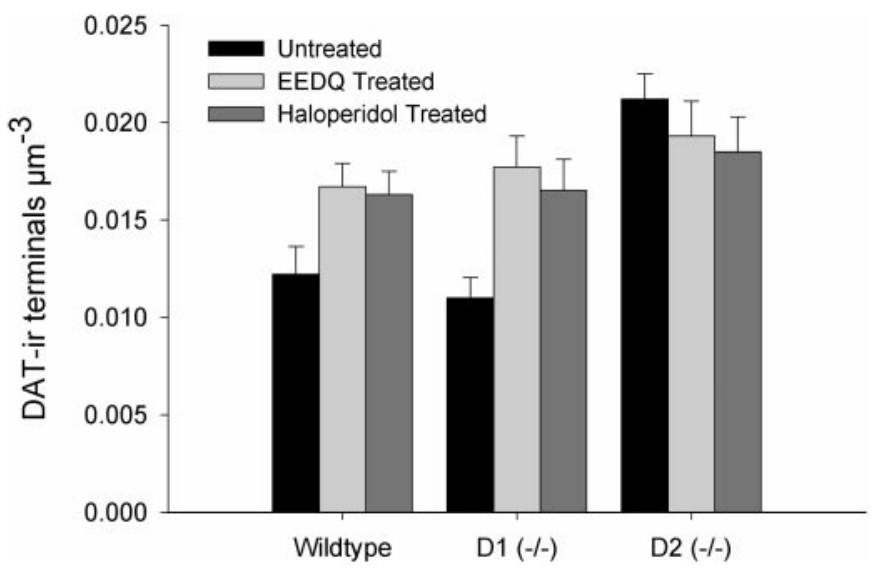

Figure 7. Histograms of density of DAT-IR terminals (mean \pm SD) in the dorsal $\mathrm{CPu}$ of $\mathrm{Wt}, \mathrm{D} 1(-/-)$ and $\mathrm{D} 2(-/-)$ mice, treated with haloperidol and EEDQ. There was no significant difference in density of terminals in untreated Wts and D1 $(-/-)$ mice however, treatment with either antagonist resulted in significantly increased density of terminals in both types of mice. Density of terminals in untreated D2 $(-/-)$ mice was higher than in treated Wts and D1 $(-/-)$ mice yet, treatment with either haloperidol or EEDQ had no significant effect on the terminal densities seen in the D2 $(-/-)$ mice.

of terminal arbor size and regenerative sprouting remains unknown. However, because the presynaptic receptor is expressed at a higher level and has a role in regulating the firing rate and propagation of action potentials as well as DA synthesis and release (Cooper et al., 1996), we hypothesize that this receptor is most likely to be the major player regulating proliferation and sprouting in SNpc neurons. Recently it was reported that D2 agonists may delay and reduce dyskinesia in Parkinson's disease (Rascol et al., 2000). It is of interest to speculate whether use of D2 agonists in Parkinson's disease may result in reduced compensatory sprouting and hence reduced dyskinesia but at the cost of increased severity of the disease because of reduction in regenerative sprouting mechanism.

Although striatal dopamine levels in D1(-/-) mice were elevated, as previously described (El-Ghundi et al., 1998), dopamine activity was markedly reduced. This suggests that the behavior of $\mathrm{D} 1(-/-)$ mice is not explained by enhanced dopaminergic activity but by some other mechanism. On the other hand, despite our finding of increased dopamine activity in D2(-/-) mice, their behavior is normal in most respects, suggesting that postsynaptic compensation has occurred (Clifford et al., 2000). It must be stressed however that DA measures in this study are not synaptic DA but the levels of total DA (including extracellular DA and vesicular DA) and DOPAC. Although these are useful markers of DA storage and turnover, a more detailed examination of synaptic function is required before drawing firm conclusions about the synaptic effects of DA in these mutants. Nevertheless, it is widely held that the presynaptic D2R regulates DA synthesis and release (Cooper et al., 1996), and it seems likely that absence of its influence has resulted in increased DA activity and sprouting in the D2 $(-/-)$ mutants. These studies were conducted on genetically manipulated mice and, because D2Rs are normally expressed early in development (Drago et al., 1998), it is difficult to ignore potential developmental compensatory effects. These effects may have been reflected in both the absolute number and the proportion of TH-IR-positive nigral neurons as well as the density of DAT-IR terminals in the striatum of the D1(-/-) and D2 $(-/-)$ mice.

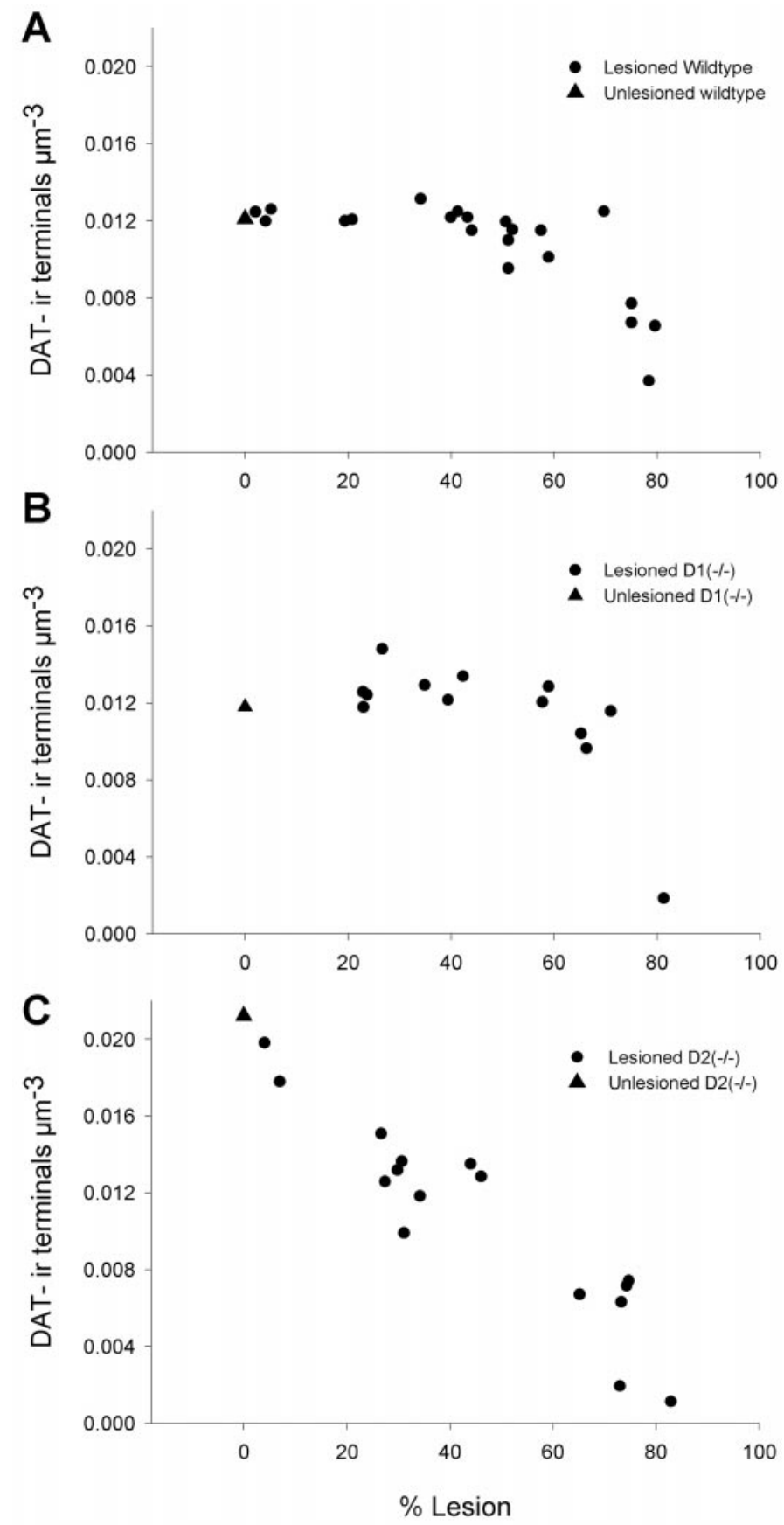

Figure 8. Plots of density of DAT-IR terminals in the CPu against the size of SNpc lesion. $A$, Density of DAT-IR terminals in Wt is maintained until $\sim 75 \%$ SNpc neurons are lost, at which point terminal density rapidly falls, presumably because remaining neurons can no longer compensate through sprouting. Similarly in D1 $(-/-)$ mice $(B)$, density of DAT-IR terminals remains normal until the lesion size approaches $75 \%$, at which point density falls. In contrast, density of DAT-IR terminals in D2(-/-) mice $(C)$ is abnormally high in the absence of a lesion and falls linearly, in proportion to the neurons lost. In all three figures, triangles represent values from unlesioned animals, and circles are representative of the lesioned animals.

The reason for the reduction in the number of SNpc neurons and TH-IR SNpc neurons is not clear. Widespread changes are recognized in the dopamine receptor knock-out mice (Drago et al., 1998). Transynaptic effects, in addition to dysregulated supply of factors known to be important for survival of neurons (Bozzi 

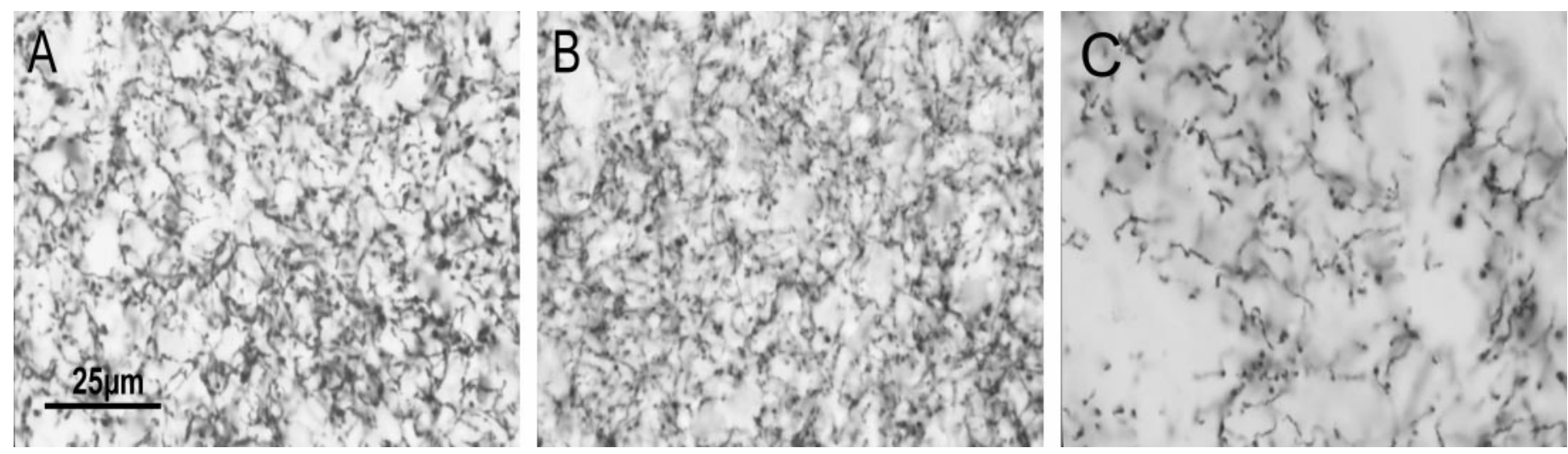

Figure 9. Photomicrograph showing examples of the density of DAT-IR terminals in animals with $\sim 70 \%$ lesions of the SNpc from Wt $(A)$, D1 $(-/-)$ $(B)$, and D2 $(-/-)(C)$ mice. Note the reduced density of DAT-IR terminals in a $70 \%$ lesioned D2 animal.

and Borrelli, 1999), may be important. Furthermore, chronic DA receptor stimulation and blockade may also have effects on both TH and L-aromatic amino acid decarboxylase enzyme activity and mRNA levels (Cho et al., 1997). The presynaptic location of the D2R and the direct input of the D1R-positive terminals on the TH-positive elements (Caille et al., 1996) provide further potential mechanisms for the modulation of the growth of nigrostriatal cells and the effect of transcriptional regulation. On the basis of the studies on receptor knock-out mice alone, it would be hard to assess whether the increased terminal tree was in response to reduced cell numbers or disturbances in regulation of axonal proliferation. However, the responses to receptor antagonists (haloperidol and EEDQ) and 6-OHDA lesions are clearly a response of the adult system that can be explained in the way that we have offered. Furthermore, the wild-type mice demonstrated these responses, indicating that they are generic responses to injury shared by both genetically manipulated and normal animals.

One of the reasons for using genetically manipulated animals is the absence of a pure DA receptor antagonist. Although haloperidol has a greater effect on D2R, it also acts at all DA receptors as well as other receptor systems, including the acetylcholine receptor, and some of its effects could have been mediated by actions other than through DA receptors. However, the actions of EEDQ are relatively DA receptor-specific and were similar to those of haloperidol, suggesting that this was unlikely.

There appears to be a maximum size of terminal tree, as seen in the D2 $(-/-)$ mice and in the Wt and D1 $(-/-)$ after lesions of $\sim 75 \%$. This suggests that an individual neuron can support a maximum number of terminals, and it is interesting to speculate regarding what factors might limit further expansion. These may include limitations caused by metabolic demand, oxidative stress, and axonal transport.

In summary, these findings suggest that the D2 receptor may play a role in modulating the extent of the terminal arbor of SNpc neurons. These results require further elaboration with the use of selective D2 receptor agonists and antagonists and the use of D2 isotype-specific mutants as well as investigations into the paths through which these influences are exerted.

\section{REFERENCES}

Adams JC (1981) Heavy metal intensification of DAB-based HRP reaction product. J Histochem Cytochem 29:775.

Baik JH, Picetti R, Saiardi A, Thiriet G, Dierich A, Depaulis A, Le Meur M, Borrelli E (1995) Parkinsonian-like locomotor impairment in mice lacking dopamine D2 receptors. Nature 377:424-428.
Batchelor PE, Liberatore GT, Wong JY, Porritt MJ, Frerichs F, Donnan GA, Howells DW (1999) Activated macrophages and microglia induce dopaminergic sprouting in the injured striatum and express brainderived neurotrophic factor and glial cell line-derived neurotrophic factor. J Neurosci 19:1708-1716.

Bjorklund A, Lindvall O (1984) Dopamine-containing systems in the CNS. Amsterdam: Elsevier.

Blanchard V, Chritin M, Vyas S, Savasta M, Feuerstein C, Agid Y, Javoy-Agid F, Raisman-Vozari R (1995) Long-term induction of tyrosine hydroxylase expression: compensatory response to partial degeneration of the dopaminergic nigrostriatal system in the rat brain. J Neurochem 64:1669-1679.

Blanchard V, Anglade P, Dziewczapolski G, Savasta M, Agid Y, Raisman-Vozari R (1996) Dopaminergic sprouting in the rat striatum after partial lesion of the substantia nigra. Brain Res 709:319-325.

Bozzi Y, Borrelli E (1999) Absence of the dopamine D2 receptor leads to a decreased expression of GDNF and NT-4 mRNAs in restricted brain areas. Eur J Neurosci 11:1275-1284.

Braendgaard H, Evans SM, Howard CV, Gundersen HJ (1990) The total number of neurons in the human neocortex unbiasedly estimated using optical disectors. J Microsc 157:285-304.

Caille I, Dumartin B, Bloch B (1996) Ultrastructural localization of D1 dopamine receptor immunoreactivity in rat striatonigral neurons and its relation with dopaminergic innervation. Brain Res 730:17-31.

Cheng HW, Tong J, McNeill TH (1998) Lesion-induced axon sprouting in the deafferented striatum of adult rat. Neurosci Lett 242:69-72.

Cho S, Neff NH, Hadjiconstantinou M (1997) Regulation of tyrosine hydroxylase and aromatic L-amino acid decarboxylase by dopaminergic drugs. Eur J Pharmacol 323:149-157.

Clifford JJ, Usiello A, Vallone D, Kinsella A, Borrelli E, Waddington JL (2000) Topographical evaluation of behavioural phenotype in a line of mice with targeted gene deletion of the D2 dopamine receptor. Neuropharmacology 39:382-390.

Coggeshall RE, Lekan HA (1996) Methods for determining numbers of cells and synapses: a case for more uniform standards of review. J Comp Neurol [Erratum (1996) 369:162] 364:6-15.

Cooper JR, Bloom FE, Roth RH (1996) The biochemical basis of neuropharmacology, Ed 7. New York: Oxford UP.

Creese (1982) Dopamine receptors explained. Trends Neurosci 5:40-43.

Drago J, Gerfen CR, Lachowicz JE, Steiner H, Hollon TR, Love PE, Ooi GT, Grinberg A, Lee EJ, Huang SP, Bartlett PF, Jose PA, Sibley DR, Westphal H (1994) Altered striatal function in a mutant mouse lacking D1A dopamine receptors. Proc Natl Acad Sci USA 91:12564-12568.

Drago J, Padungchaichot P, Accili D, Fuchs S (1998) Dopamine receptors and dopamine transporter in brain function and addictive behaviors: insights from targeted mouse mutants. Dev Neurosci 20:188-203.

El-Ghundi M, George SR, Drago J, Fletcher PJ, Fan T, Nguyen T, Liu C, Sibley DR, Westphal H, O'Dowd BF (1998) Disruption of dopamine D1 receptor gene expression attenuates alcohol-seeking behavior. Eur J Pharmacol 353:149-158.

Fagan AM, Gage FH (1994) Mechanisms of sprouting in the adult central nervous system: cellular responses in areas of terminal degeneration and reinnervation in the rat hippocampus. Neuroscience 58:705-725.

Fallon JH, Moore RY (1978) Catecholamine innervation of the basal forebrain. IV. Topography of the dopamine projection to the basal forebrain and neostriatum. J Comp Neurol 180:545-580.

Finkelstein DI, Stanic D, Parish CL, Tomas D, Dickson K, Horne MK (2000) Axonal sprouting following lesions of the rat substantia nigra Neuroscience 97:99-112. 
Franklin KBJ, Paxinos G (1997) The mouse brain in stereotaxic coordinates. San Diego: Academic.

Frotscher M, Heimrich B, Deller T (1997) Sprouting in the hippocampus is layer-specific. Trends Neurosci 20:218-223.

Gerfen CR, Herkenham M, Thibault J (1987) The neostriatal mosaic: II. Patch- and matrix-directed mesostriatal dopaminergic and nondopaminergic systems. J Neurosci 7:3915-3934.

Gundersen HJ, Bagger P, Bendtsen TF, Evans SM, Korbo L, Marcussen N, Moller A, Nielsen K, Nyengaard JR, Pakkenberg B, Sørensen FB, Vesterby A, West MJ (1988) The new stereological tools: disector, fractionator, nucleator and point sampled intercepts and their use in pathological research and diagnosis. APM IS 96:857-881.

Herges S, Taylor DA (1999) Modulatory effect of $p$-chlorophenylalanine microinjected into the dorsal and median raphe nuclei on cocaineinduced behaviour in the rat. Eur J Pharmacol 374:329-340.

Ho A, Blum M (1998) Induction of interleukin-1 associated with compensatory dopaminergic sprouting in the denervated striatum of young mice: model of aging and neurodegenerative disease. J Neurosci 18:5614-5629.

Hornykiewicz O (1993) Parkinson's disease and the adaptive capacity of the nigrostriatal dopamine system: possible neurochemical mechanisms. Adv Neurol 60:140-147.

Kandel ER, Schwartz JH, Jessell TM (1991) Principles of neural science, Ed 3. New York: Elsevier.

Liberatore GT, Finkelstein DI, Wong JY, Horne MK, Porritt MJ, Donnan GA, Howells DW (1999) Sprouting of dopaminergic axons after striatal injury: confirmation by markers not dependent on dopamine metabolism. Exp Neurol 159:565-573.

Missale C, Nash SR, Robinson SW, Jaber M, Caron MG (1998) Dopamine receptors: from structure to function. Physiol Rev 78:189-225.

Nelson EL, Liang CL, Sinton CM, German DC (1996) Midbrain dopaminergic neurons in the mouse: computer-assisted mapping. J Comp Neurol 369:361-371.

Onn SP, Berger TW, Stricker EM, Zigmond MJ (1986) Effects of intra- ventricular 6-hydroxydopamine on the dopaminergic innervation of striatum: histochemical and neurochemical analysis. Brain Res 376:8-19.

Raisman G, Field PM (1973) A quantitative investigation of the development of collateral reinnervation after partial deafferentation of the septal nuclei. Brain Res 50:241-264.

Rascol O, Brooks DJ, Korczyn AD, De Deyn PP, Clarke CE, Lang AE (2000) A five-year study of the incidence of dyskinesia in patients with early Parkinson's disease who were treated with ropinirole or levodopa. 056 Study Group. N Engl J Med 342:1484-1491.

Thomas J, Wang J, Takubo H, Sheng J, de Jesus S, Bankiewicz KS (1994) A 6-hydroxydopamine-induced selective parkinsonian rat model: further biochemical and behavioral characterization. Exp Neurol 126:159-167.

Usiello A, Baik JH, Rouge-Pont F, Picetti R, Dierich A, LeMeur M, Piazza PV, Borrelli E (2000) Distinct functions of the two isoforms of dopamine D2 receptors. Nature 408:199-203.

Weiner DM, Levey AI, Sunahara RK, Niznik HB, O'Dowd BF, Seeman $\mathrm{P}$, Brann MR (1991) D1 and D2 dopamine receptor mRNA in rat brain. Proc Natl Acad Sci USA 88:1859-1863.

West MJ, Gundersen HJ (1990) Unbiased stereological estimation of the number of neurons in the human hippocampus. J Comp Neurol 296:1-22.

West MJ, Slomianka L, Gundersen HJ (1991) Unbiased stereological estimation of the total number of neurons in the subdivisions of the rat hippocampus using the optical fractionator. Anat Rec 231:482-497.

West MJ, Ostergaard K, Andreassen OA, Finsen B (1996) Estimation of the number of somatostatin neurons in the striatum: an in situ hybridization study using the optical fractionator method. J Comp Neurol 370:11-22.

Zigmond MJ, Acheson AL, Stachowiak MK, Stricker EM (1984) Neurochemical compensation after nigrostriatal bundle injury in an animal model of preclinical Parkinsonism. Arch Neurol 41:856-861. 